with President Nixon's much-heralded National Cancer Act, and responsible for an increase in cancer research funding from $\$ 180$ million in 1970 to almost $\$ 900$ million in 1978.

No one is claiming that the money has been entirely wasted. Much good science has been carried out under the cancer programme, and despite occasional widely-publicised lapses, few are prepared publicly to identify specific projects which they feel should not have been funded.

But various factors have led to a cooling off in Congress' initial enthusiasm for a massively-financed cancer research programme, and to increasing demands for a visible pay-off from its investment. These factors include data showing that, in spite of all the research and clinical advances, deaths from cancer continue to increase, and the growing evidence that many cancers are due to environmental causes, accessible to preventitive rather than curative techniques.

Congress' frustration at the lack of tangible results reinforces the view of those scientists who criticised the whole "target-oriented approach", to biomedical research funding from the beginning. The fear, however, is that a failure of strategy could result in a general disillusionment with the whole research enterprise, affecting both its basic and applied aspects.

Dr Arthur Kornberg, for example, professor of biochemistry at Stanford University, claims that it is very rare for a crash programme of biomedical research to succeed in its objective, but warns that failure also carries its price. "Progress in medicine rests on fundamental advances. You harm people by trying to do things prematurely-you destroy your credibility, and the whole of science suffers. We have seen this happen in recent years, and people are discouraged from entering a field which has come to be regarded as bad science."

Dr Kornberg criticises the extent to which research workers are increasingly required to keep their eyes on a fixed target. "At present we have to boot-leg under various guises if we want to carry out fundamental research. This has both the spirit and the content of scientific investigation."

The task therefore facing the biomedical community, confronted by an apparent failure to come up with the goods that congress-many feel unjustly -has demanded, is how to make it respectable to be seen giving money to basic research in the biological and medical sciences. Criticism of the cancer programme, for example, will be to no purpose if the net result is an overall reduction in NIH research funds, rather than a redirection of

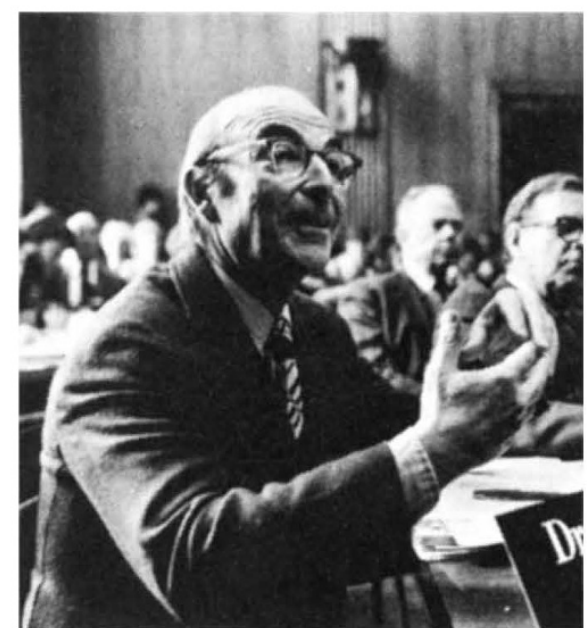

Dr Arthur Kornberg

funds towards basic research.

Furthermore Congress has no direct control over the way that the directors of the various NIH institutes distribute the funds allocated to them. A suggestion that each institute be required to spend at least $30 \%$ of its budget on basic research would be "a mistake" according to Dr Donald Frederickson, Director of NIH, who points out that most institutes do this already.

The best that scientists can hope for is some recommendation from Congress that it would like to see the various institutes upgrade basic research, a suggestion to be checked later against actual performance. "I feel that some of the institutes have tended to overemphasise target research at the expense of basic research because that was what Congress wanted. But Congress might now take the opportunity to communicate its belief in the importance of basic research," Dr Seymour Kety, Professor of Psychiatry at Harvard University and a past scientific director of the National Institute for Mental Health told the Senate Appropriations Subcommittee.

So far, the response of several key Congressmen has been relatively favourable. Sensing a growing disillusionment with the target-oriented approach to research funding, they are prepared to back the case that the long-term solutions lie in supporting basic research.

Mr Eagleton, for example, told the scientists that his subcommittee had "become aware of the pitfalls brought on by the proliferations of targeted research programmes." And Representative Paul D. Rogers, Chairman of the House Subcommittee on Health and the Environment, has promised to introduce a research training grants bill that would provide an extra $\$ 220$ million in 1979 .

But the case is far from conceded. Cancer research still has powerful supporters who, while accepting that it is the quality rather than the quantity of research that matters, claim that this means more rather than less money. And there remains the widespread feeling in many quarters-frequently voiced, for example, by Senator Edward Kennedy-that medical scientists should be required to produce results of visible social usefulness to justify the large investment of public funds that they receive.

Thus in spite of a significant increase in federal support for basic research in the proposed budget for 1979, basic biomedical science is unlikely to achieve its " $100 \%$ parity" with the boom years of the late $1960 \mathrm{~s}$. At least not in the near future. The most that scientists can hope for is that they can encourage the pendulum to swing a little faster in their direction.

David Dickson

\section{Lederberg named President of Rockefeller University}

Professor Joshua Lederberg, Chairman of the Department of Genetics at the Stanford University School of Medicine, and Nobel prize winner in 1958 for his work on the organisation of genetic material in bacteria, has been elected President of the Rockefeller University in New York. Professor Lederberg will take up his appointment from 1 July and succeed Dr Frederick Seitz.

\section{UK science budget announced for 1978/9}

Spending on science through the $U K$ research councils will be up by more than $2 \%$ in real terms in 1978/9, claim the Advisory Board for the Research Councils ( $A B R C$ ) following agreement between the Board and the Secretary of State for Education and Science on expenditure levels. The Science Budget, which funds the research councils, Natural History Museum and Royal Society, is 1256 million at 1977 prices; the Science Research Council get 1139 million of it. The figures include two increases recently authorised, one for a recurrent $£ 4$ million following a slight easing of the economic situation, the second for a once-off $£ 4.5$ million to stimulate the construction industry.

The distribution of the budget still reflects $A B R C$ 's intention gradually to redeploy resources away from big science but there is now sufficient leeway with the extra money for one person at SRC headquarters to describe the mood there as "reasonable satisfaction, even modified rapture". 